6 kongresu ISCHE w Wolfenbüttel. Grupa ta spotkała się na posiedzeniu naukowym w bieżącym roku również w Bambergu.

Nad obradami kongresu przewijało się larum prof. dra Teruhisa Horio z Uniwersytetu w Tokio, który w swym referacie plenarnym pt.: The Emergence and Development of Educational Studies in Modern Japan ostrzegał, iż nasza konsumpcyjna codzienność powoduje na całym świecie wielkie niebezpieczeństwa i zagrożenia dla rozwoju nauk humanistycznych, w tym i nauk o wychowaniu.

Warto wspomnieć, iż mimo permanentnych problemów natury finansowej 12 polskich pracowników naukowych wzięło udział w kongresie, w tym znaczna liczba młodych adeptów nauki. Dla części z nich był to pierwszy udział w kongresie międzynarodowym. Polscy pracownicy naukowi znaleźli się na trzecim miejscu pod względem liczby uczestników po Niemcach (16), Hiszpanach (13) i Anglikach (13).

Wszyscy Polacy byli niezwykle aktywni i przygotowali nastepujące referaty: Bogusław Chmielowski (Akademia Wych. Fizycznego - Katowice), pt. Die Kulturpādagogik von Bogdan Suchodolski (1903 - 1992); Joanna Elżbieta Dąbrowska (Filia UW w Białymstoku) pt. Image of the Faculty: A Year After; Adam Fijalkowski (UW) pt. Auxiliary Scholar Disciplines of History of Education studies; Wlodzimierz Goriszowski (WSP Kielce - Filia w Piotrkowie Tryb.) pt Elements of Managerial Conceptions in teaching of School Management Staff; Jan Hellwig (UAM-Poznañ) pt. Die Forschungen über Geschichte der Erziehung in Poznań; Czesław Majorek (WSP-Kraków) pt. Herbartian Educational Theory in the Ninetecnth Century. Polish Teacher Seminars; Lech Mokrzecki i Józef Zerko (UG) pt. Regionalism in Scientific Research and in the Program of Teaching, History of Education in Poland; Ewa Romanowska (Filia UW w Bialymstoku) pt. Education as a Factor in the Development of Belorussian Culture in Poland; Joanna Katarzyna Sadowska (Filia UW w Białymstoku) pt. The Educational Reform of 1932 in Poland.

W kongresie uczestniczyli także prof. prof. Teresa Wróblewska i Lucjan Olszewski (oboje WSP Kielce, Filia w Piotrkowie Trybunalskim).

Polskie referaty i zawarta $w$ nich problematyka głównie o akcentach narodowych, cieszyły się dużym zainteresowaniem. Wynikalo to także $\mathrm{z}$ tego, że następny 18 kongres ISCHE odbędzie się w Polsce, w siedzibie WSP, w Krakowie, w dniach od 6 do 9 sierpnia 1996 r. a jego temat został sformułowany następująco: Schooling in changing societies. Historical and comparative perspectives (c. 1750 - 1996).

Kongres dokonał swoistego historycznego przeglądu rozwoju nauk o wychowaniu. Mimo wspomnianego wołania na trwoge zarysowany obraz wydaje się być optymistyczny. Na uwage zasługiwały ewidentne postępy w rozwoju nauk o wychowaniu w poszczególnych krajach, regionach kulturowych a nawet na kontynentach. Brak było jednak syntez holistycznych, które w moim przekonaniu mogłyby w pewnym sensie powstać, gdyby wykorzystać całość materiałów referatowych przedstawionych na kongresie. Organizatorzy wydali jednak jedynie abstrakty. Przydatna byłaby publikacja pełnych materiałów, co jednak ze względów finansowych prawdopodobnie nie nastąpi.

Jan Hellwig

\title{
Spotkanie naukowe historyków wychowania przedszkolnego Bamberg (RFN) 9-12.09.1995 r.
}

Dwunaste już międzynarodowe spotkanie naukowe historyków wychowania przedszkolnego odbyło się tym razem w malowniczym mieście bawarskim Bambergu.

Głównym problemem przewijającym się zarówno w referatach dyskusji, wystawach opracowań było analizowanie zagadnienia „Do kogo należy dziecko? Od 1800 r. do czasów wspólczesnych" (,To whom does the young child belong? 1800 till the present"). 
W kameralnej atmosferze istniały doskonate warunki dla wymiany informacji o faktach z przeszłości, jak i o teoretycznym podejściu do rozwiązywania wielu trudnych problemów współczesnych w tej dziedzinie.

Nieco marginalny, ale wywołujący zainteresowanie uczestników był mój referat, jako jedynego uczestnika z Polski, pt. Badania nad historią wychowania przedszkolnego w Polsce (Die Forschungen U'ber die Geschichte der vorschulischen Erziehung in Polen). Wskazano w nim min. na ważniejsze ośrodki badań nad historią wychowania przedszkolnego, zakres problematyki badań uprawianych w tej dziedzinie w Polsce, rolę i znaczenie pierwszej syntezy w tej dziedzinie, jaką jest podręcznik „Zarys dziejów wychowania przedszkolnego", Warszawa 1978 (w dwóch tomach), napisany przez prof. Wandę Bobrowską-Nowak z Uniwersytetu Śląskiego, a także wkład periodyków historycznych i pedagogicznych, jak Przegląd Historyczno-Oświatowy, Wychowanie w Przedszkolu, czy Biuletyn Historii Wychowania wydawany przez Zaklad Historii Wychowania Wydziału Studiów Edukacyjnych Uniwersytetu im. Adama Mickiewicza w Poznaniu wespół z Sekcją Historii Wychowania Polskiego Towarzystwa Pedagogicznego.

Wskazano również na znaczenie gromadzenia zbiorów w tym zakresie np. przez Ośrodek Informacji Współczesnej i Dokumentacji w Warszawie oraz Regionalną Izbę Pamiątek Oświatowych w Poznaniu (RIPO).

Przedmiotem szczególnego zainteresowania uczestników były prace magisterskie obejmujące fragmentaryczne problemy dziejów wychowania przedszkolnego powstałe w Zakładzie Historii Wychowania UAM w Poznaniu w oparciu o materiały źródłowe zgromadzone zarówno w warszawskim ośrodku, jak i poznańskim RIPO, udostępnione uczestnikom oraz prezentowane na wystawie. Ich powstanie oceniono jako waże działanie dla gromadzenia opracowań przyczynkarskich mogących stanowić podstawę do przyszłych syntez w dziedzinie dziejów wychowania przedszkolnego, których ciągle brak.

W czasie obrad zaprezentowano też nową książkę Evy Balke (Norwegia), przewodniczącej OMEP (Międzynarodowej Organizacji Wychowania Przedszkolnego) The History of Early Childhood Education Models for the Kindergartens/Nursery Schools of our Time.

Jak już wspomniałem, spotkanie miało w dużej mierze charakter kameralny. Związane to było z wysokimi kosztami udziału (opłata organizacyjna, przejazdy, hotele, wyżywienie, itp.), także znacznymi dla naukowców z krajów zachodnich i pozaeuropejskich. Zjechało się zaledwie 14 uczestników, podczas gdy np. w Pradze w 1992 r. było ich ponad 150. Niekorzystne okazalo się oddzielne organizowanie obrad i niejako odlączenie ich od dorocznych obrad sesji ISCHE.

Uczestnicy bawarskiego spotkania naukowego reprezentowali nastepujące kraje: Francję (1), Izrael (1), Niemcy (5), Nowegię (1), Polskę (1), Szwecję (3), Węgry (2).

Uczestnicy mogli także otrzymać Index of papers wydany pod kierownictwem Frédérica Dajez i Gû̉ntera Erninga zawierający wykaz referatów, ich tematykę oraz nazwiska autorów, wygłoszonych w ciągu 10 lat (1984-1993) podczas dorocznych posiedzeń ECE. Można się z niego dowiedzieć m.in, że w tym czasie siedmiu polskich uczonych wygłosiło podczas posiedzeń stałej grupy roboczej ECE przy ISCHE 11 referatów, które zostały opublikowane w całości lub w formie abstraktów w materiałach sesyjnych. Jest to niewątpliwie poważny wkład polskiej nauki w miegdzynarodowy ruch naukowy na rzecz idei opracowywania dziejów wychowania przedszkolnego.

Obrady toczyły się głównie w języku angielskim, ale także francuskim i niemieckim.

Moderatorami obrad byli dr Eva Szabolcs (Węgry), przewodnicząca ECE oraz dr Günter Erning - sekretarz ECE.

Następne 13 spotkanie naukowe postanowiono znów połączyć z 18 sesją ISCHE, która odbędzie się w dniach 6 - 9 sierpnia 1996 r. w Polsce w Krakowie. Jej temat ustalono w następującym brzemieniu: Historical concepts of early childhood education in international perspectives.

Konferencja przyczyniła się do stymulacji badań nad dziejami wychowania przedszkolnego i ich upowszechniania.

Jan Hellwig 